\title{
Epidemiological Studies of Piglet Diarrhoea in Intensively Managed Danish Sow Herds
}

\section{Rotavirus infection}

\author{
By Birgitta Svensmark, Knud Nielsen, Kristlan Dalsgaard and Preben Willeberg \\ Departments of Internal Medicine and Forensic and State Veterinary Medicine, \\ Royal Veterinary and Agricultural Unıversity, Copenhagen \\ and the State Veterınary Institute for Virus Research, Lindholm, Kalvehave, Denmark.
}

\begin{abstract}
Svensmark, B., K. Nielsen, K. Dalsgaard and P. Willeberg: Epidemiological studies of piglet diarrhoea in intensively managed Danish sow herds. III. Rotavirus infection. Acta vet. scand. 1989, 30, 63-70. - The prevalence of rotavirus infection was studied in 1090 litters from 26 sow herds. Samples of normal, semifluid and watery stools were examined for rotavirus by an ELISA-test on faeces. Rotavirus was detected in $77 \%$ of the herds and in $30.5 \%$ of the litters (prevalence rates). The highest prevalence rate was seen in piglets between 21 and 41 days of age. Gilts' litters had a very high prevalence during the first week of life. Apart from this, no difference was found between litters from gilts and older sows. Rotavirus was detected more frequently in semiliquid, loose stools than in normal or watery stools, and an association between virus detection and diarrhoea could not be demonstrated. However, litters which shedded rotavirus during the suckling period had lower weight gains and higher incidence rates of respiratory diseases than virus-free litters. Litters weaned at 2 weeks in battery cages had slightly increased risk of shedding rotavirus compared to litters weaned in more traditional systems. The study revealed that rotavirus is widespread in Danish swine herds. The findings give evidence to suggest that the type of mild diarrhoea in 3-week-old piglets known as steatorrhoea or "white scours" may be associated with rotavirus infection, possibly in combination with $E$ coll and other agents. The high prevalence in piglets weaned at 2 weeks plus the higher morbidity and mortality among such piglets sustain the conclusion that piglets should not be weaned before 3 weeks of age or below a body weight of 6-7 kg.
\end{abstract}

mortalıty; morbidity; prevalence; ELISA; faecal test.

\section{Introduction}

Since the first description of rotavirus infection in calves (Mebus et al. 1969) numerous reports have appeared on the isolation of rotavirus from various species. From the mid-seventies, the infection has been described in piglets (Rodger et al. 1975, Lecce et al. 1976, Woode et al. 1976, Janke 1985, Nilsson et al. 1984). Prevalence studies have revealed that the infection is widespread in swine herds, either as asymptomatic infec- tions or associated with diarrhoea (Bohl et al. 1978, de Leeuw et al 1979, Corthier et al. 1980, Askaa et al. 1980, Askaa \& Bloch 1981, 1984).

The present report describes the occurrence and epidemiology of rotavirus infection in a number of intensively managed Danish sow herds.

\section{Material and methods}

The study comprised 26 herds, of which 23 
participated in the socalled "Field Tests" (under the "National Committee for Pig Breeding"). All herds had problems with diarrhoea in suckling piglets or weaners. Thirteen herds were visited once, the remaining 13 herds 3-10 times through a period of 15 months. At each visit faecal samples were collected from at least 10 litters. A total of 1090 litters from birth to 11 weeks of age were examined. Mixed faecal samples were collected from the pen floor. Care was taken to obtain faeces from several piglets. Faeces were graded in 3 categories according to consistency: normal, semifluid or watery. The samples were deep frozen and mailed to the State Veterinary Institute for Virus Research where they were screened for rotavirus by means of an ELISA technique (Askaa \& Bloch 1981). A bacteriological culture was done on samples from diarrhoic litters.

In the 23 herds participating in the Field Tests data on production were recorded. The production data collected and the statistical methods employed have been described in the first paper of the present series (Svensmark et al. 1989a).

\section{Results}

\section{Herd prevalence rate}

Rotavirus was demonstrated in 20 of the $\mathbf{2 6}$ herds $(77 \%)$. Five of the herds where virus was not detected were examined only once, the 6 th herd had 3 negative test results.

\section{Litter prevalence rate}

Among the 1090 litters, rotavirus was detected in $322(30.5 \%)$. Herd history was insufficient in 314 litters and these were not considered further. In the remaining 776 litters, 471 were suckling and 305 weaned. Prevalence rates were higher in weaners than in suckling piglets (Table 1).
Table 1. Rotavirus in suckling and weaned piglets.

\begin{tabular}{lcc}
\hline & Number of litters & Prevalence rate \% \\
\hline Sucklıng & 471 & 26.3 \\
Weaned & 305 & 37.4 \\
\hline Total & 776 & 30.7 \\
\hline
\end{tabular}

Age

The highest prevalence was seen in piglets in the age group between 21 and 41 days (Fig. 1). There was no difference between suckling and weaned piglets in this respect. Most herds practised early weaning (mean weaning age 30 days).

\section{Parity of the sow}

When considering the suckling period as a whole, there was no difference in rotavirus prevalence between litters from gilts and from older sows. However, if the suckling period was subdivided, litters of gilts had approx. 4 times higher prevalence rate during the first week of life than did litters of older sows, whereas no difference was seen in the older age groups (Fig. 2).

\section{Diarrhoea}

Rotavirus was detected more frequently in loose, semiliquid stools than in normal or watery stools (Table 2). In the 23 herds participating in the Field Tests, symptoms in the litters were recorded (Svensmark et al. 1989a), and it was thus possible to study the relationship between diarrhoea and detection of rotavirus. No such relationship was found, neither in suckling nor in weaned litters (Table 3). Pathogenic E. coli were isolated frequently from litters with watery diarrhoea but not from loose stools. Due to the recording system employed in the Field Tests, it was not possible to evaluate whether there was a combined effect of 


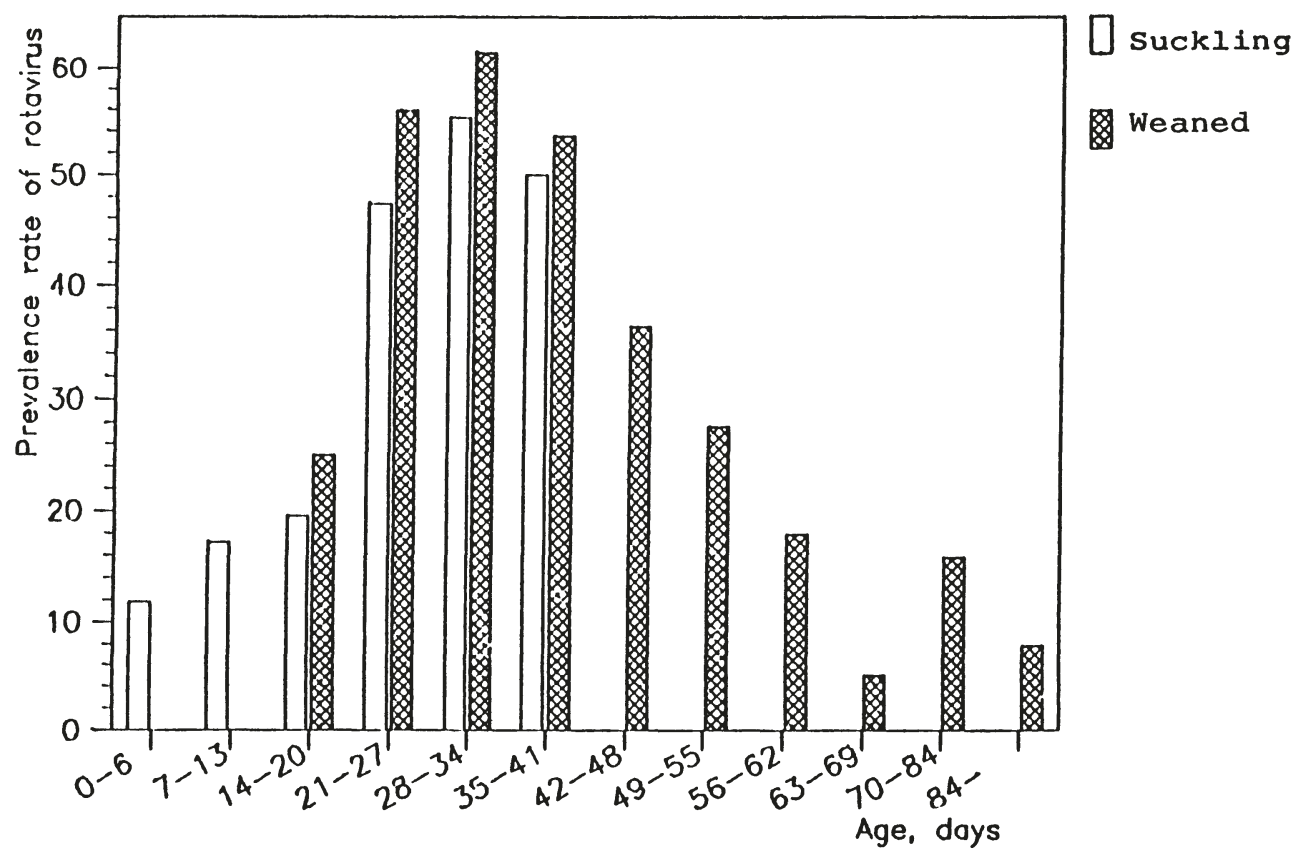

Figure 1. Rotavirus and age among sucklıng and weaned piglets.

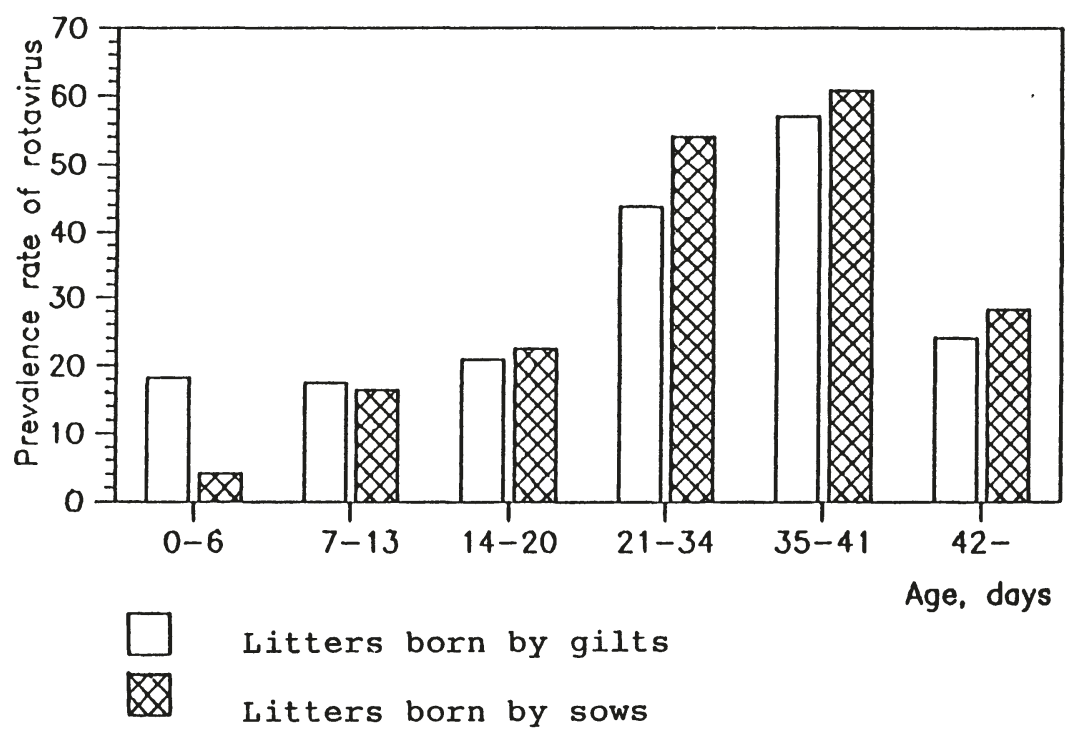

Figure 2. Rotavirus in different age groups of piglets born by gilts and sows. 
Table 2. Rotavirus in stools of different consistency.

\begin{tabular}{lccl}
\hline $\begin{array}{l}\text { Consistency } \\
\text { of stools }\end{array}$ & $\begin{array}{c}\text { Number of } \\
\text { litters }\end{array}$ & $\begin{array}{c}\text { Prevalence } \\
\text { rate } \%\end{array}$ & $\begin{array}{c}\text { Relative } \\
\text { rsk }\end{array}$ \\
\hline Normal & 372 & 28.2 & 1 \\
Loose & 489 & 36.4 & $1.3^{*}$ \\
Liquid & 74 & 20.3 & $0.7 \mathrm{NS}$ \\
\hline
\end{tabular}

NS non-signıficant: $\quad \mathrm{p}>0.05$

$$
\begin{array}{rlr}
* & : & 0.05>p>0.01 \\
{ }^{* *} & : & 0.01>p>0.001 \\
* * * & : & \mathrm{p}<0.001
\end{array}
$$

\begin{tabular}{|c|c|c|c|c|}
\hline & Diarrhoea & $\begin{array}{c}\text { Number of } \\
\text { litters }\end{array}$ & $\begin{array}{l}\text { Prevalence } \\
\text { rate } \%\end{array}$ & $\begin{array}{c}\text { Relative } \\
\text { risk }\end{array}$ \\
\hline Suckling & $\begin{array}{l}+ \\
-\end{array}$ & $\begin{array}{r}66 \\
392\end{array}$ & $\begin{array}{l}27.3 \\
26.5\end{array}$ & $\begin{array}{l}1.0 \mathrm{NS} \\
1\end{array}$ \\
\hline Weaned & $\begin{array}{l}+ \\
-\end{array}$ & $\begin{array}{r}28 \\
272\end{array}$ & $\begin{array}{l}32.1 \\
36.8\end{array}$ & $\begin{array}{l}0.9 \mathrm{NS} \\
1\end{array}$ \\
\hline
\end{tabular}

Table 3. Rotavirus and recording of diarrhoea in the litter.

$E$. coll and rotavirus upon the severity of diarrhoea.

\section{Respiratory disease}

Litters in which rotavirus was detected had a higher incidence of respiratory disease. The relative risk was 6.1 compared to rotavirusfree litters. The difference was significant $(0.05>p>0.01)$. Mortality in infected litters was, on the other hand, not significantly greater than in non-infected litters.

\section{Weight gain}

Piglets from infected litters weighed $0.5 \mathrm{~kg}$ less at 30 days of age than non-infected piglets (Table 4). Further, the occurrence of uneven litters at weaning was higher when rotavirus had been detected in the litter during the suckling period. However, the difference was not significant (Table 5).
Table 4. Occurrence of rotavirus during the suckling penod and average weight of piglets at 30 days of age.

\begin{tabular}{lcc}
\hline $\begin{array}{l}\text { Occurrence of } \\
\text { rotavirus }\end{array}$ & Number of litters & $\begin{array}{c}\text { Weight at 30 days } \\
(\mathrm{kg})\end{array}$ \\
\hline+ & 122 & 6.7 \\
- & 336 & $7.2^{* *}$ \\
\hline
\end{tabular}

\begin{tabular}{|c|c|c|c|c|}
\hline \multirow[b]{2}{*}{$\begin{array}{l}\text { Occurrence } \\
\text { of rotavirus }\end{array}$} & \multirow[b]{2}{*}{$\begin{array}{c}\text { Number of } \\
\text { litters }\end{array}$} & \multirow[b]{2}{*}{$\begin{array}{l}\text { Frequency } \\
\text { of uneven } \\
\text { litters (\%) }\end{array}$} & \multicolumn{2}{|c|}{ Relative risk } \\
\hline & & & Crude & $\begin{array}{l}\text { Adjusted for } \\
\text { diarrhoea }\end{array}$ \\
\hline+ & 122 & 8.2 & $1.8 \mathrm{NS}$ & $1.4 \mathrm{NS}$ \\
\hline- & 336 & 4.5 & 1 & 1 \\
\hline
\end{tabular}

Table 5. Occurrence of rotavirus durnng the suckling period and uneven litters at weaning.

\section{Weaning age}

In 3 herds under the Field Tests weaning at 2 and 4 weeks were compared. Half of the litters were weaned at approx. 2 weeks (av. 17 days) in so-called battery cages, whereas the remaining litters were weaned at 4 weeks (av. 33 days) in mini pens or flat deck pens. Prevalence rates in the 2 groups are shown in Table 6. There was a higher risk that early weaned piglets in battery cages would be infected, but the difference was not significant. Also, the incidence rates of diarrhoea were not significantly different in the 2 groups although there was a trend towards a

Table 6. Age at weaning and incidence rate of post-weaning diarrhoea and prevalence rate of rotavirus excretion in litters with diarrhoea.

\begin{tabular}{lccc}
\hline $\begin{array}{l}\text { Age at } \\
\text { weaning } \\
\text { (weeks) }\end{array}$ & $\begin{array}{c}\text { Number of } \\
\text { litters }\end{array}$ & $\begin{array}{c}\text { Incidence rate } \\
\text { of diarrhoea (\%) }\end{array}$ & $\begin{array}{c}\text { Prevalence rate } \\
\text { of rotavirus in } \\
\text { litters w } \\
\text { diarrhoea (\%) }\end{array}$ \\
\hline 2 & 123 & $11.3 \mathrm{NS}$ & $36.1 \mathrm{NS}$ \\
4 & 113 & 7.8 & 31.3 \\
\hline
\end{tabular}




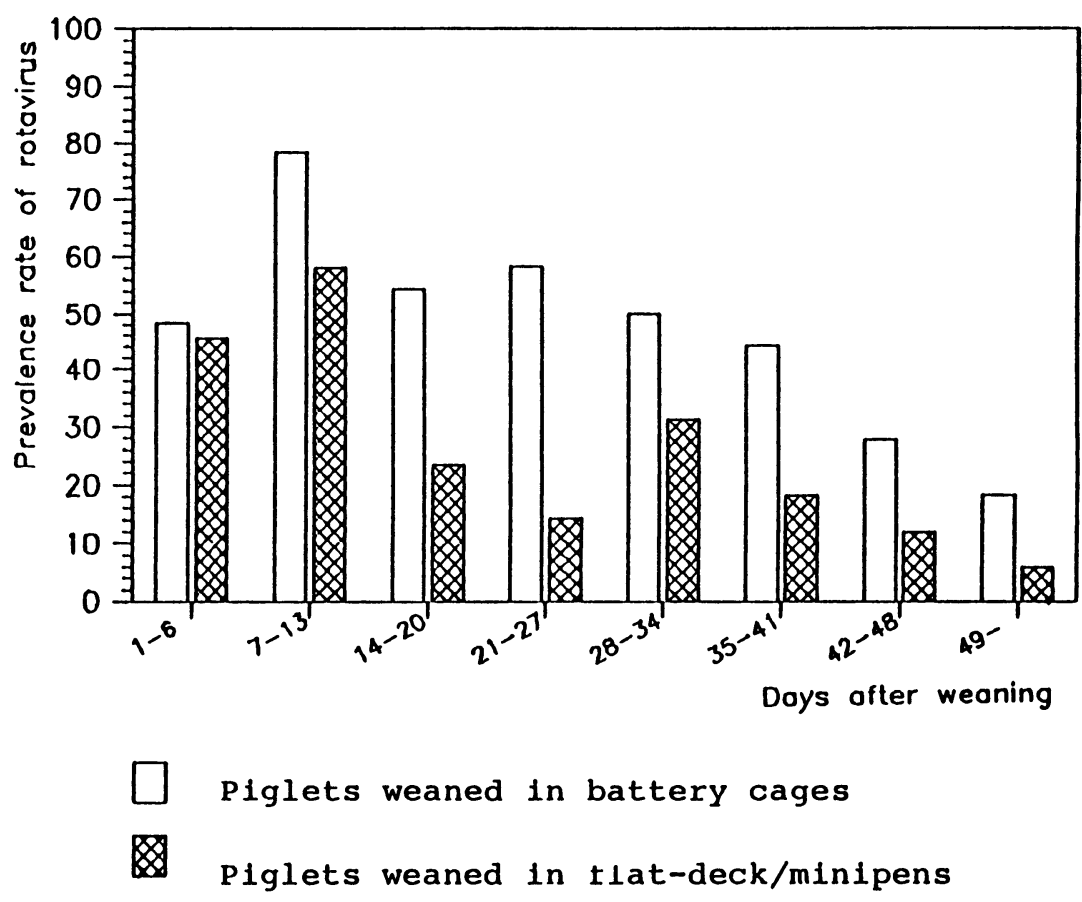

Figure 3. Rotavirus and time after weaning in piglets weaned at 2 weeks in battery cages and piglets weaned at 4 weeks in flat-deck or minipens.

higher incidence in piglets weaned at 2 weeks and, likewise, a non-significant trend towards a higher prevalence rate of rotavirus excretion in diarrhoeic litters (Table 7). In both weaning systems, the peak prevalence of rotavirus infection was seen 7-13 days after weaning, when approx. $80 \%$ of piglets weaned at 2 weeks and approx. $60 \%$ of piglets weaned at 4 weeks shedded virus (Fig. 3). During the following weeks the prevalence rates declined in both groups, but the decline was more pronounced in piglets weaned at 4 weeks. Accordingly, irrespective of weaning age, the highest rate of infection occurred in 3-5 week-old piglets.

Design of farrowing pen

In 2 herds under the Field Tests, the effect of farrowing pen design was studied. Half of the farrowing pens were traditional, i. e. the sow was loose, the floor was concrete with straw as bedding, and the area of the pen was above $6 \mathrm{~m}^{2}$. The other farrowing pens were intensive, i. a. the sow was tethered, the floor was drained (perforated or slatted) and the area of the pen was approx. $3 \mathrm{~m}^{2}$. It appears from Table 7 that rotavirus was detected more often in the traditional pen than in the intensive pen. The difference, however, was not statistically significant. When litters were followed during the suckling period an increase in prevalence of virus detection was noted with time. As shown in Fig. 4, infection pressure in the intensive farrowing pen was very low during the first 2 weeks after birth, after which there was a 
steep increase. In the traditional pen the increase occurred more gradually during the suckling period up to 5 weeks of age.

Table 7. Type of farrowing pen and incidence rate of diarrhoea and prevalence rate of rotavirus excretion.

\begin{tabular}{lcccc}
\hline & & \multicolumn{3}{c}{$\begin{array}{c}\text { Prevalence rate of rotavirus } \\
\text { excretion (\%) }\end{array}$} \\
\cline { 3 - 5 } $\begin{array}{l}\text { Type of } \\
\text { farrowing } \\
\text { pen }\end{array}$ & $\begin{array}{c}\text { Number } \\
\text { of litters }\end{array}$ & $\begin{array}{c}\text { Incidence } \\
\text { rate of } \\
\text { diarrhoea } \\
(\%)\end{array}$ & $\begin{array}{l}\text { Diarrhoic } \\
\text { litters }\end{array}$ & $\begin{array}{c}\text { All } \\
\text { litters }\end{array}$ \\
\hline $\begin{array}{l}\text { Tradi- } \\
\text { tional }\end{array}$ & 176 & 9.1 & 31.1 & 29.5 \\
Intensive & 152 & 8.6 & $24.4 \mathrm{NS}$ & $19.7 \mathrm{NS}$ \\
\hline
\end{tabular}

\section{Discussion}

Rotavirus was detected in $77 \%$ of the intensively managed herds and in approx. $30 \%$ of the litters studied here. In comparison, an- other Danish study (Askaa \& Bloch 1981) revealed that $55 \%$ of 42 herds were infected and Corthier et al. 1980) reported a point prevalence rate of $24 \%$ in 42 French herds. The higher prevalence rate in the present study may be explained by the fact that the majority of the herds were examined several times over a period of approx. 15 months, whereas the reports cited above were based upon a single or a few herd visits. There is a good correlation between the $77 \%$ prevalence found here and the finding that more than $75 \%$ of sows have circulating antibodies to rotavirus (Corthier et al. 1980, Hess \& Bachmann 1981). The highest prevalence rate of virus excretion was seen in 3-5 week-old piglets with semiliquid stools. Otherwise, there was no association between the occurrence of diarrhoea in the litters and detection of virus. This may be due, in part, to the registration system employed in the (a)

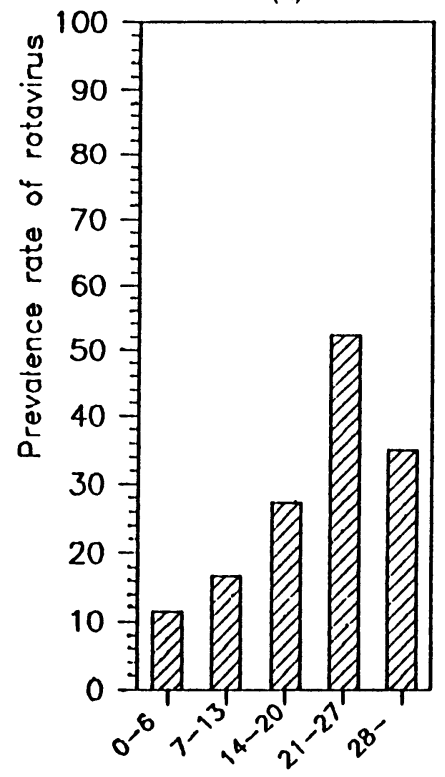

Age, doys (b)

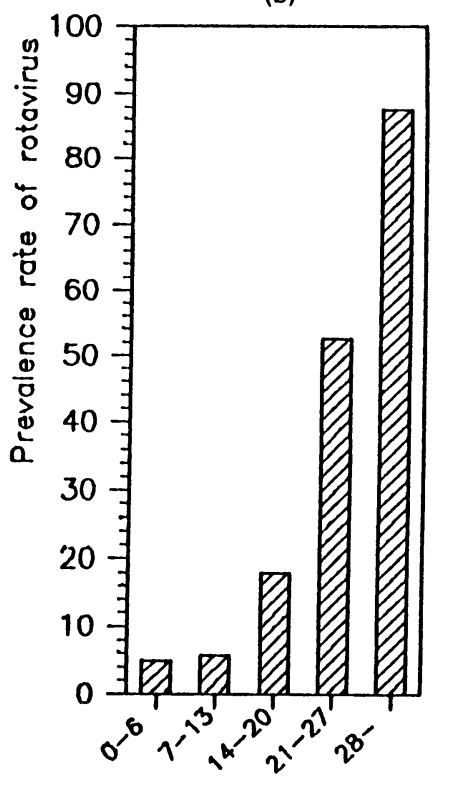

Age, doys

Figure 4. Rotavirus and age of piglets in traditional (a) and intensive (b) farrowing pens. 
Field Tests to which most of the herds were affiliated. Thus, diarrhoea in a litter was recorded only if more than $25 \%$ of the piglets were scouring or if medical treatment was required. Thus, the type of diarrhoea occurring frequently in 3-5 week-old piglets and known as "steatorrhoea", "3-week-diarrhoea" or "white scours" would often escape registration in the system employed here. However, the finding that virus was detected most frequently in 3-5 week-old piglets with loose stools and the finding that litters in which virus was detected during the suckling period had a poor performance, i. e. a reduced litter weight at weaning and at $\mathbf{3 0}$ days of age, would indicate that rotavirus is of ethiological significance in steatorrhoea of piglets, possibly in association with other agents ( $E$ coll, Isospora suls a. o.), a conclusion that is in keeping with the findings reported by other authors (Bohl et al. 1978, Tzıpori et al. 1980, Askaa \& Bloch 1981, 1984, Nilsson et al. 1984). Also, experimental inoculation of rotavirus into neonatal piglets is regularly followed by mild diarrhoea (Askaa \& Bloch 1984, Janke 1985, Svensmark et al. 1989c).

The present study revealed that intensive management is not invariably associated with higher morbidity or mortality. The first paper in the present series (Svensmark et al. 1989a) reported a lower incidence of diarrhoea in intensive farrowing pens - i.e. small pens with perforated or slatted floor and fixated sows - than in more traditional farrowing pens (loose sows, concrete floor with bedding), and the present report has revealed that the excretion of rotavirus was low in intensive farrowing pens during the first few weeks after birth. These results should probably be explained by a higher hygiene level in the intensively managed herds. E. g. farrowings are synchronized in units that are high-pressure washed before new sows are introduced. On the other hand, sows in intensified production systems have less contact with neighbouring sows and less possibilities to consume faecal material from the pen floor, which might imply that their antibody levels to rotavirus and other pathogens are lower than in more traditional production systems with loose sows. There is an increasing trend towards fixation of sows, not only in the farrowing unit but throughout the reproductive cycle, including the pregnancy unit. Studies are needed to evaluate whether such production patterns influence the development of maternal immunity and thus may be of significance for the colostral supply of antibodies to the neonatal piglet.

Very early weaning in battery cages was associated with a high rate of excretion of rotavirus and, as shown previously (Svensmark et al. 1989b), there was a markedly increased morbidity and mortality in such systems. The results reported here sustain the conclusion that piglets should not be weaned before 3 weeks of age or below a body weight of 6-7 kg.

\section{Acknowledgement}

This study was aided by grants from "Forsøgsleder R. Nørtoft Thomsens legat" and "Hans Kiers Fond".

\section{References}

Askaa $J$, Bloch B. Detection of porcine rotavirus by EM, ELISA and CIET. Acta vet. scand. 1981, 22, 32-38.

Askaa $J$, Bloch B: Infection in piglets with a porcine rotalike virus. Experimental inoculation and ultrastructural examination. Arch. Virol. 1984, 80, 291-303.

Askaa J, Sørensen KJ, Moslet U: Rotavirus som årsag til diarre hos grise. (Rotavirus as a cause of diarrhoea in piglets). Dansk Vet.-Tidsskr. $1980,63,730-735$. 
Bohl EH, Kohler EM, Salf LJ, Cross RF, Agnes $A G$, Thell $K V \cdot$ Rotavirus as a cause of diarrhea in pigs. J. Amer vet. med. Ass. 1978, $172,458-463$.

Corthier G, Vannier P, Gosselin F, Tillon JP. Rotavirus in France: Serological surveys, virus 1solation and experimental infections. IPVS Congress Proceedings, Copenhagen 1980, p. 127.

Hess $R G$, Bachmann $P A \cdot$ Distribution of antibodies to rotavirus in serum and lacteal secretions of naturally infected swine and their sucklıng pigs. Amer. J. vet. Res. 1981, 42, 1149-1152.

Janke $B H$ Rotavirus and enterovirus infection in neonatal pigs. Pathogenesis of single and mixed infections. Thesis, Univ. Columbia 1985, Diss. Abstr. 1985, 45, 2506.

Lecce JG, King $M W$, Mock $R$ Reovirus-like agent associated with fatal diarrhea in neonatal pigs. Infect. Immunol. 1976, 14, 816825.

Leeuw PW de, Ellens DJ, Hilbink FW Rotavirus-associated recurrent diarrhoea in nursing piglets. INSERM 1979, 90, 349-354.

Mebus CA, Underdahl NR, Rhodes MP. Calf diarrhea (scours) reproduced with a virus from a field outbreak. Univ. Nebraska Res. Bull. 1969, 233, 1-16.

Nilsson $O$, Martınsson K, Persson E: Epıdemiology of porcine neonatal steatorrhoea in Sweden. 1. Prevalence and clinical significance of coccidial and rotaviral infections. Nord. Vet.Med. 1984, 36, 103-110.

Rodger SM, Craven JA, Williams I: Demonstration of reovirus-like partıcles in intestinal contents of piglets with diarrhoea. Aust. vet. J. 1975, 51, 536.

Svensmark B, Jorsal SE, Nielsen K, Willeberg P: Epidemiological studies of piglet diarrhoea in intensively managed Danish sow herds. I. Preweaning diarrhoea. Acta vet. scand. 1989a, 30, 43-53.

Ibld . II. Post-weaning diarrhoea. Acta vet. scand. 1989b, 30, 55-62.

Svensmark B, Askaa J, Wolstrup C, Nielsen K: Epidemılogical studies of piglet diarrhoea in intensively managed Danish sow herds. IV. Pathogenicity of porcine rotavirus. Acta vet. scand. 1989c, 30, 71-76.

Tzıpori S, Makın T, Smith T, Chandler D. The role of rotavirus in the pathogenesis of piglet enteritis. IPVS Congress Proceedings, Copenhagen 1980, p. 128.

Woode GN, Bridger J, Hall GA, Jones JM, Jackson $G$. The isolation of reovirus-like agents (rotaviruses) from acute gastroenteritis of piglets. J. med. Microbiol. 1976, 9, 203-209.

\section{Sammendrag \\ Epıdemiologiske undersøgelser af diarre hos grise i intensivt drevne sobesatninger \\ III Rotavirus infektion}

Prævalensen af rotavirusinfektion blev undersøgt i 1090 kuld i 26 sobesætninger. Kuld med normal, løs eller vandig afføring blev undersøgt ved en ELISA-metode udført på fæces. Rotavirus blev påvist $177 \%$ af besætningerne og i $30,5 \%$ af kuldene. Højeste prævalensrate blev påvist hos grıse i alderen 21-41 dage. Gyltekuld havde meget høj prævalensrate $i$ første leveuge, efter dette tidsrum påvistes ingen forskel mellem kuld efter søer af forskellıg paritet. Virus påvistes hyppıgere fra fæces af løs konsistens end fra normal eller vandig afføring, og det var ikke muligt at påvise en sikker sammenhæng mellem viruspåvisning og diarre i kuldene. Imidlertid havde kuld, der udskilte rotavirus 1 diegivnıngsperioden, dårligere tilvækst og højere incidensrate af luftvejssygdomme end virusfri kuld. Kuld der fravænnedes ved 2 ugers alderen 1 batteribure havde hyppigere virusudskillelse end kuld fravænnet i flat deck eller ministier.

Undersøgelsen har vist, at rotavirus er vidt udbredt i dansk smågriseproduktion. Resultaterne giver baggrund for at antage, at såkaldt 3-ugers diarre eller steatorrhoe kan være associeret med rotavırusinfektion, muligvis i samspil med $E$. coll og andre agentia. Den høje prævalensrate hos tidligt fravænnede kuld og den høje morbiditet og mortalitet i disse kuld støtter konklusionen, at grise ikke bør fravænnes under 3 uger gamle eller under en vægt på 6-7 kg.

(Recelved April 20, 1988; accepted June 22, 1988).

Reprints may be requested from: Knud Nielsen, Department of Internal Medicine, Royal Veterinary and Agricultural University, 13 Bülowsvej, DK-1870 Frederiksberg C., Denmark. 